Agrovoc descriptors: brassica oleracea; spacing; thrips (genus); thrips tabaci; crop yield; damage; quality; dimensions; crop losses

Agris category code: H10, F01

COBISS Code 1.01

\title{
Yield and quality of early cabbage (Brassica oleracea L. var. capitata) in response to within-row plant spacing
}

\author{
Dragan ŽNIDARČIČ ${ }^{1}$, Nina KACJAN-MARŠIĆ ${ }^{2}$, Jože OSVALD ${ }^{3}$, Tomaž \\ POŽRL ${ }^{4}$, Stanislav TRDAN ${ }^{5}$
}

Received May 8, 2007; accepted June 20, 2007.

Delo je prispelo 8. maja 2007; sprejeto 20. junija 2007.

\begin{abstract}
The plant spacing of early cabbage (Brassica oleracea L. var. capitata) was studied at the Experimental Field of the Biotechnical Faculty in Ljubljana, during the 2001 and 2002 growing season. The cultivars, which included 'Vestri', 'Parel', 'Delphi', 'Destiny' and 'Hermes', were each spaced at 20,30 and $40 \mathrm{~cm}$ within rows and $30 \mathrm{~cm}$ between rows or populations equivalent to $166,000,108,000$ and 82,000 plants $\mathrm{ha}^{-1}$. The experimental variables measured were marketable yield (per head and per hectare), yield characteristics (head diameter and head volume), quality characteristics (core volume, head density, soluble solids and dry matter) and onion thrips damage ratings. There was no interaction effect of cultivar and planting spacing on the measured variables. Marketable yield per head, head diameter and volume, core volume and head density generally increased as the within-row plant spacing increased, whereas, dry matter was significantly decreased at lower plant spacing. Soluble solids were not affected by plant spacing. The yield potential of cabbage was higher at cv. 'Vestri' than at the other cultivars. The onion thrips damage rating was severe at the lowest plant spacing and contributed to the reduced yield. A higher damage rating was established in the cv. 'Parel' but this didn't have a statistically significant influence on the weight loss of yield.
\end{abstract}

Key words: Brassica oleracea, cabbage, yield, head quality, onion thrips, damage

\section{IZVLEČEK}

\section{PRIDELEK IN KAKOVOST ZGODNJEGA ZELJA (Brassica oleracea L. var. capitata) V ODVISNOSTI OD RAZDALJE V VRSTI}

Poskus s sadilnimi razdaljami zgodnjega zelja (Brassica oleracea L. var. capitata) je bil opravljen na Laboratorijskem polju Biotehniške fakultete v letih 2001 in 2002. Medvrstna razdalja za pet kultivarjev zelja ('Vestri', 'Parel', 'Delphi', 'Destiny' in 'Hermes') je znašala 30

1 M. Sc. Agr., Biotechnical Faculty, University of Ljubljana, SI-1111 Ljubljana, Jamnikarjeva 101

2 Assistant Prof., Ph. D., ibid

3 Prof., Ph. D., ibid

4 M. Sc. Food. Tech., ibid

5 Assistant Prof., Ph. D., ibid 
$\mathrm{cm}$, medtem ko so bile razdalje $v$ vrsti 20,30 in $40 \mathrm{~cm}$, kar, preračunano na površino enega ha, pomeni $166.000,108.000$ oz. 82.000 rastlin. Ugotavljali smo tržni pridelek (na glavo in na ha), lastnosti pridelka (premer glave in prostornino glave), kvalitativne lastnosti (prostornino vretena, gostoto glave, suho snov in sušino) in ocenili poškodbe, ki jih je povzročil tobakov resar. Med dejavnikoma kultivar in gostota sajenja ni prišlo do interakcije, ki bi vplivala na opazovane lastnosti. Tržni pridelek glav, premer in prostornina glav, prostornina vreten in gostota glav so na splošno naraščali $z$ večanjem razdalje $v$ vrsti, medtem ko se je pri najmanjši gostoti sušina značilno zmanjšala. Sadilna razdalja ni vplivala na vsebnost suhe snovi. Cv. 'Vestri' se je v primerjavi z preostalimi kultivarji izkazal kot kultivar z možnostjo doseganja najvišjih pridelkov. Poškodbe, ki jih je povzročil tobakov resar, so bile največe pri najmanjši sadilni razdalji in so bile razlog za zmanjšanje pridelka. Največ poškodb je pretrpel cv. 'Parel', a to ni statistično značilno vplivalo na izgubo pridelka.

Ključne besede: Brassica oleracea, zelje, pridelek, kakovost glav, tobakov resar, poškodbe

\section{INTRODUCTION}

Cabbage (Brassica oleracea L. var. capitata) is a typical vegetable crop of Slovenia with a cultivated area of around 450 ha, which represents $20.1 \%$ of the field in production in this country (Statistical Office RS, 2005). Slovenia has the favourable agroclimatic conditions for the production ob cabbage varieties for fresh market and for processing, namely.

Plant population studies are common features of many horticultural crops, including cabbage (Stoffela and Bryan, 1988). There are several citations in the literature that provide information relative to optimum plant population evaluations for cabbage that been conducted over the past 30 years (Day, 1986; Stoffela and Fleming, 1990; Lal, 1996; Stepanović et al., 2000). A very common range in optimum plant population recommendations for cabbage is for stand densities of 20,000 to 70,000 plants per ha (Ghanti et al., 1982; Tendaj and Kuzyk, 2001; Kumar and Rawat, 2002). But results of these reports have been inconclusive. Cabbage yield and quality response to plant density has been shown to be influenced by several factors such as the plant genotype, climate condition, soil, water regime, nutrient status, market requirements and many others (Knavel and Herron, 1981; Parmar et al., 1999; Tiwari et al., 2003).

Increasing plant population with cabbage has the potential for increasing yield and profit. Although in cabbage, high plant density reduced head size and head weight (Csizinsky and Schuster, 1985) a greater number of heads per unit area increased total yield (Stepanović et al., 2000).

Though many authors have reported some information on the plant density of different varieties of cabbage, studies under Slovenia agro climatic conditions are limited. There were two major objectives to this experiment. First we estimated which plant spacing and which variety are optimal for cabbage production. Second, we conducted to determine whether varieties differ with respect to their susceptibility of resistance to onion thrips (Thrips tabaci Lindeman) which is prevalent in Slovenian cabbage fields. 


\section{MATERIAL AND METHODS}

\section{Location and climate conditions}

The observation were made over two years at the Experimental Field $\left(46^{\circ} 04^{\prime} \mathrm{N}, 14^{\circ} 31^{\prime} \mathrm{W}\right.$, $300 \mathrm{~m}$ above sea level) of the Biotechnical Faculty in Ljubljana, Slovenia. The climate at the site is characterized by typical temperate continental climate. The average growing period rainfall is $527.9 \mathrm{~mm}$ and cumulated temperatures were $341.2^{\circ} \mathrm{C}$.

Primary weather data for the experimental period were obtained from the meteorological station located in the experimental field, which is situated at distance of $500 \mathrm{~m}$ from the experimental plot. Each of the experimental years was warmer than the long term average, although in 2001, the temperature in April was lower. The 2001 growing period was relatively hotter than the 2002 period. Between 10 July and 20 July, the maximum temperature was $24.6{ }^{\circ} \mathrm{C}$ in 2001 as compared to $20.7^{\circ} \mathrm{C}$ in 2002 . The total precipitation received in 2001 was relatively lower than in the long-term average, but there were some heavy rains in May. However, crop growth was not affected by drought because to supplement low precipitation, irrigation was applied several times during the growing period.

Table 1: Climatologically data for Ljubljana (Slovenia) during the experimental period

\begin{tabular}{|l|ccc|ccc|}
\hline \multirow{2}{*}{ Month } & \multicolumn{3}{|c|}{ Mean temperature $\left({ }^{\circ} \mathrm{C}\right)$} & \multicolumn{3}{c|}{ Sums of precipitation $(\mathrm{mm})$} \\
& 2001 & 2002 & Long-term & 2001 & 2002 & Long-term ${ }^{1}$ \\
\hline April & 17.1 & 14.7 & 17.2 & 71.7 & 90.7 & 117.5 \\
May & 18.3 & 21.1 & 17.8 & 147.3 & 175.6 & 148.4 \\
June & 21.9 & 21.3 & 19.9 & 32.6 & 127.0 & 121.8 \\
July & 22.9 & 20.1 & 19.1 & 89.6 & 186.6 & 140.2 \\
\hline
\end{tabular}

30 years mean in Ljubljana, Slovenia

\section{Experimental design}

The experimental design was a split-plot within a randomized complete block design with three replications. The main plot treatments consisted of five early cabbage varieties, namely 'Vestri', 'Parel', 'Delphi', 'Destiny' and 'Hermes' and each subunit consisted of three spacing densities. Varieties which are widely grown by local growers were included in the experiment for comparison purposes. The above spacing resulted in plant population of $166,000108,000$ and 82,000 plants ha ${ }^{-2}$, respectively. The constant distance between rows was $30 \mathrm{~cm}$. Withinrow spacing used were $20 \mathrm{~cm}, 30 \mathrm{~cm}$ and $40 \mathrm{~cm}$. The experimental unit consisted of three rows within sixteen plants in each row.

Seeding was done in 72 cell trays in the greenhouse in mid-March. Plants were hardened-off prior to transplanting in the field. Transplanting about 30 days old seedlings to raised beds was done on April 17, 2001, and April 21, 2002. Black polyethylene mulch and drip tape (Ttape TSX 500 Model, T-systems International; 0.25-m emitter spacing) were used as typically done in commercial field in Slovenia. Fertilizer was applied preplant incorporated and during the season through drip emitter using water soluble 21-21-21 NPK. No insecticide was applied in order to see the effect of onion thrips resistance on yield and quality.

The heads were harvested from each treatment beginning when the variety appeared to be approaching horticultural maturity by the usual visual criteria. A sample of eight heads per treatment was cut and split longitudinally to measured the following parameters: marketable head weight, head polar and equatorial diameters and core length and base width. The head density was calculated as previously reported (Pearson, 1983), using the marketable weight of individual head and average of the equatorial and polar head diameters. The volumes of heads and cores were estimated using the sphere and cone formula, respectively (Kleiheinz and Wszelaki, 2003). The marketable head weight data was converted into values marketable 
yield per hectare. Soluble solids concentration of the expressed juice was determined using a hand-held Atago PR1 refractometer. Head dry weight was determined by drying the leaves in oven at approximately $60{ }^{\circ} \mathrm{C}$ until a constant weight was reached.

After frame leaves were removed we also visual inspected the presence of onion thrips damage. The four heads per treatment was peeled to remove leaves damaged by thrips feeding. The amount of peeled leaves was weighed to indicate a measure of thrips tolerance. The leaves damaged was rated on severity scale of 1 (no damage) up to 6 (severe damage) (Stoner and Shelton, 1988). According Trdan et al. (2005) the scale was slightly modified, because additionally the interval between 26 and $50 \%$ of damaged leaf surface was taken into consideration.

\section{RESULTS AND DISCUSSION}

Because there was no significant difference in interaction between variety and planting density for all measured variables, analyses of the results is focused on the differences within the main effects variables, which included variety and planting density. Significant differences are marked with different letters.

\section{Influence of plant spacing on yield and yield characteristics}

By mean values reported in Table 2, it emerges that head production attained highest yields in 2002. These conclusions can statistically confirm for marketable yield per head as well as per hectare. It is difficult to determine, however, the precise influence of environmental factors in this study on head formation. The temperature is primary variable for plant growth and development (Masaya et al., 2004). The results suggest the deleterious effect of hot weather conditions on cabbage head formation. Between 10 July and 20 July, 2001 the plants exposed to higher temperature for $3.9^{\circ} \mathrm{C}$ in comparison the same period in 2002. At this stage of development (expansion of internal head leaves), the heads had produced more than $20 \%$ of their biomass. Generally, the temperatures above $24{ }^{\circ} \mathrm{C}$ are not suited to cabbage production (Kahn et al., 2007). These results are in agreement with those obtained by Radovich et al. (2004). These researches pointed out that temperature appears to the factor contributing most to the variation in growth observed between years. It is not known however, what the critical duration of high temperature of exposure is required to cause limiting growth in cabbage.

As within-row spacing decreased yield per head increased. The highest marketable

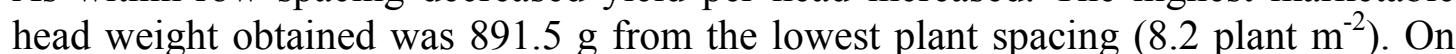
the other hand no significant differences in marketable yield per hectare were found among highest and lowest plant spacing. Our results indicate that plants at the lower rate were able to compensate for the lower plant numbers by increasing head volume. For all plant spacing, there was a positive linear relationship between head weight and head volume (data not shown). The 'Vestri' produced the highest marketable yield per head and per hectare. A comparison of the head diameter of the seasons revealed quite different results. The trend was similar in head weight. A reduction in head weight was the cause for the difference in the head diameter. Head diameter generally increased with decreased plant spacing. Semuli (2005) mentioned that it is possible that as plant spacing was reduced, competition for nutrients, light, air and moisture increased which would have resulted in decreased diameter and weight of heads. 
Stofella and Fleming (1990) reported quadratic increases in the cabbage head height and head width as intra-row spacing was increased from 8 to $38 \mathrm{~cm}$. The lowest plant spacing resulted in significantly wider equatorial diameter than the polar one.

Table 2: Influence of plant spacing on marketable yield, head diameter and head volume

\begin{tabular}{|l|cc|cc|c|}
\hline \multirow{2}{*}{ Treatment } & \multicolumn{2}{|c|}{$\begin{array}{c}\text { Marketable yield } \\
\mathrm{head}^{-1}(\mathrm{~g})\end{array}$} & \multicolumn{2}{c|}{ Head diameter $(\mathrm{cm})$} & Head volume \\
& & & & & \\
polar & equatorial & & \\
& & & & & \\
2001 & & & & \\
2002 & $418.5 \mathrm{a}$ & $49.4 \mathrm{a}$ & $10.1 \mathrm{a}$ & $11.4 \mathrm{a}$ & $562.4 \mathrm{a}$ \\
Cultivar & $862.6 \mathrm{~b}$ & $101.7 \mathrm{~b}$ & $11.2 \mathrm{~b}$ & $13.0 \mathrm{~b}$ & $783.7 \mathrm{~b}$ \\
Vestri & & & & & \\
Hermes & $810.8 \mathrm{a}$ & $95.6 \mathrm{a}$ & $11.0 \mathrm{~b}$ & $12.0 \mathrm{a}$ & $750.0 \mathrm{~b}$ \\
Delphi & $623.8 \mathrm{~b}$ & $73.6 \mathrm{~b}$ & $10.8 \mathrm{~b}$ & $11.7 \mathrm{a}$ & $708.6 \mathrm{~b}$ \\
Destiny & $629.3 \mathrm{~b}$ & $74.3 \mathrm{~b}$ & $10.2 \mathrm{a}$ & $12.0 \mathrm{a}$ & $582.4 \mathrm{a}$ \\
Parel & $562.9 \mathrm{c}$ & $66.4 \mathrm{c}$ & $11.1 \mathrm{~b}$ & $12.3 \mathrm{a}$ & $769.5 \mathrm{~b}$ \\
Spacing $\left(\mathrm{m}^{-2}\right)$ & $604.5 \mathrm{~b}$ & $71.3 \mathrm{~b}$ & $10.0 \mathrm{a}$ & $13.0 \mathrm{~b}$ & $556.2 \mathrm{a}$ \\
16.6 & & & & & \\
10.8 & $428.0 \mathrm{a}$ & $71.0 \mathrm{a}$ & $9.6 \mathrm{a}$ & $11.2 \mathrm{a}$ & $480.5 \mathrm{a}$ \\
8.2 & $602.5 \mathrm{~b}$ & $65.0 \mathrm{~b}$ & $12.7 \mathrm{~b}$ & $12.0 \mathrm{~b}$ & $678.4 \mathrm{~b}$ \\
& $891.5 \mathrm{c}$ & $73.1 \mathrm{a}$ & $16.6 \mathrm{c}$ & $13.1 \mathrm{c}$ & $860.5 \mathrm{c}$ \\
\hline
\end{tabular}

\section{Influence of plant spacing on quality characteristics}

Plant spacing showed significant effects on quality characteristics (Table 3). Core volume was significantly increased by decreasing plant spacing. The highest core volume $\left(43.7 \mathrm{~cm}^{-3}\right)$ was recorded in heads from the lowest spacing. It was found that the mean percent of core volume which occupied the head didn't varying among various levels of plant spacing. A comparison of percent of core volume per head among cultivars revealed a significant difference. Highest measurements for this parameter were obtained at 'Vestri' (7.6\%) and lowest at 'Destiny' $(3.2 \%)$.

The head density, a primary indicator of horticultural maturity (Radovich et al., 2004), appeared to be significantly influenced by plant spacing. Although Kleinheinz and Wszelaki (2003) reported that the head density generally exceed $0.70 \mathrm{~g} \mathrm{~cm}^{-3}$, in our experiment these values in some cases were lower. For example, the maximum plant spacing of 16.6 plants $\mathrm{m}^{-2}$ was achieved minimum head density $0.62 \mathrm{~g} \mathrm{~cm}^{-3}$. Across the cabbage cultivars evaluated, 'Destiny' was achieved only $0.60 \mathrm{~g} \mathrm{~cm}^{-3}$.

The percentage of soluble solids was higher in the low plant spacing, followed by the medium spacing and the high plant spacing. But these values were not significantly affected. 
The percent of dry matter, which consist both of soluble and insoluble carbohydrates, was significantly influenced by plant spacing. According Raupp (2000) percentage of dry matter is an important reference parameter, and is somewhat significant as well to a consumer who does not want to buy watery products. Heads grown at low spacing produced less dry matter than at high spacing. These results are in agreement with those obtained by Agele at al. (1999) on tomato and Siomos (1999) on pak choi. On the other hand, our results are not conformity with those of Koutsos and KoutsikaSotiriou (2001) who mentioned that increasing the volume of heads decreased the dry matter percent. In 2002, heads produced cca 20\% more dry matter than in 2001, probably due to the lower temperature in June.

Table 3: Influence of plant spacing on quality of cabbage

\begin{tabular}{|l|cc|c|c|c|}
\hline Treatment & \multicolumn{2}{|c|}{$\begin{array}{c}\text { Core volume } \\
\left(\mathrm{cm}^{-3}\right)\end{array}$} & $\begin{array}{c}\text { Head density } \\
\left(\% \mathrm{head}^{-1}\right)\end{array}$ & $\begin{array}{c}\text { Soluble solids } \\
\left(\mathrm{g} \mathrm{cm}^{-3}\right)\end{array}$ & $\begin{array}{c}\text { Dry matter } \\
(\%)\end{array}$ \\
\hline Year & & & & & \\
2001 & $17.1 \mathrm{a}$ & $3.4 \mathrm{a}$ & $0.70 \mathrm{a}$ & $5.8 \mathrm{a}$ & $7.8 \mathrm{a}$ \\
2002 & $55.6 \mathrm{~b}$ & $7.7 \mathrm{~b}$ & $0.84 \mathrm{~b}$ & $5.6 \mathrm{a}$ & $9.6 \mathrm{~b}$ \\
Cultivar & & & & & \\
Vestri & $54.4 \mathrm{a}$ & $7.6 \mathrm{a}$ & $0.84 \mathrm{a}$ & $5.5 \mathrm{a}$ & $10.5 \mathrm{a}$ \\
Hermes & $35.1 \mathrm{~b}$ & $4.9 \mathrm{c}$ & $0.73 \mathrm{~b}$ & $5.0 \mathrm{a}$ & $9.0 \mathrm{~b}$ \\
Delphi & $30.6 \mathrm{c}$ & $5.2 \mathrm{c}$ & $0.78 \mathrm{~b}$ & $5.9 \mathrm{a}$ & $8.9 \mathrm{~b}$ \\
Destiny & $54.4 \mathrm{a}$ & $3.2 \mathrm{~d}$ & $0.60 \mathrm{c}$ & $5.4 \mathrm{a}$ & $10.4 \mathrm{a}$ \\
Parel & $36.8 \mathrm{~b}$ & $6.8 \mathrm{~b}$ & $0.78 \mathrm{~b}$ & $5.2 \mathrm{a}$ & $7.2 \mathrm{c}$ \\
Spacing $\left(m^{-2}\right)$ & & & & & \\
16.6 & $28.7 \mathrm{a}$ & $6.2 \mathrm{a}$ & $0.62 \mathrm{a}$ & $5.3 \mathrm{a}$ & $10.6 \mathrm{a}$ \\
10.8 & $36.8 \mathrm{~b}$ & $5.5 \mathrm{a}$ & $0.76 \mathrm{~b}$ & $5.6 \mathrm{a}$ & $9.6 \mathrm{~b}$ \\
8.2 & $43.7 \mathrm{c}$ & $6.0 \mathrm{a}$ & $0.89 \mathrm{c}$ & $5.8 \mathrm{a}$ & $8.8 \mathrm{c}$ \\
\hline
\end{tabular}

\section{Influence of plant spacing on thrips damage}

The thrips damage ratings of the head differed greatly (Table 4). The thrips pressure on cabbage was much larger in 2001 than in 2002. High temperatures during first year should be resulting in a greater extent of damage on the cabbage heads. Temperatures as high as $32{ }^{\circ} \mathrm{C}$ were recorded on several occasions during head formation in June and July. Thrips tabaci, which are polyphagous insects, much rather remain inside of cabbage heads where they are protected against sunburn. Because thrips remain inside of cabbage heads for longer in this type of weather than in the "mean year" (Tamo et al., 1993), the extent of their damage is greater. The other reason may have caused by the heavy rainy summer in 2002. The extreme population drop in early June (data not shown) corresponded to a heavy rainfall event. However, the trend of susceptibility of each variety's was similar in both years. In 2001 and 2002 we concluded the lowest damage in the 'Vestri', the highest in the 'Parel' and smaller statistical differences the 
'Hermes', 'Delphi' and 'Destiny'. These differences were more apparent in 2001 than in 2002. The lowest damage ratings was found in the most densely plant spacing (16.6 plants $\left.\mathrm{m}^{-2}\right)$ and the highest in the least densely planted category $\left(8.2\right.$ plants $\left.\mathrm{m}^{-2}\right)$.

Table 4: Influence of thrips damage on heads characteristics

\begin{tabular}{|l|c|cc|}
\hline Treatment & Damage ratings & \multicolumn{2}{|c|}{ Peeled leaves } \\
\hline Year & & weight $(\mathrm{g})$ & $\left(\%\right.$ head $\left.^{-1}\right)$ \\
2001 & $1.76 \mathrm{a}$ & $162.5 \mathrm{a}$ & $28.1 \mathrm{a}$ \\
2002 & $1.33 \mathrm{~b}$ & $235.7 \mathrm{~b}$ & $20.9 \mathrm{~b}$ \\
Cultivar & & & \\
Vestri & $1.33 \mathrm{a}$ & $168.8 \mathrm{a}$ & $19.3 \mathrm{a}$ \\
Hermes & $1.55 \mathrm{~b}$ & $178.1 \mathrm{~b}$ & $23.0 \mathrm{~b}$ \\
Delphi & $1.65 \mathrm{~b}$ & $217.3 \mathrm{c}$ & $27.6 \mathrm{c}$ \\
Destiny & $1.72 \mathrm{~b}$ & $214.0 \mathrm{c}$ & $28.2 \mathrm{c}$ \\
Parel & $1.96 \mathrm{c}$ & $202.8 \mathrm{c}$ & $26.5 \mathrm{c}$ \\
Spacing $\left(m^{-2}\right)$ & & & $22.8 \mathrm{a}$ \\
16.6 & $1.42 \mathrm{a}$ & $111.6 \mathrm{a}$ & $25.0 \mathrm{~b}$ \\
10.8 & $1.65 \mathrm{~b}$ & $185.1 \mathrm{~b}$ & $28.7 \mathrm{c}$ \\
8.2 & $1.85 \mathrm{c}$ & $300.7 \mathrm{c}$ & \\
\hline
\end{tabular}

The weight loss of yield (peeled leaves) due to onion thrips damage on the cabbage heads varied between the two years and was larger in 2001 when the cabbage was exposed higher attack of thrips tabaci. Similar results were obtained in terms of percent loss of yield. 'Vestri' clearly showed a tendency to have the least \% loss of yield. Statistically significant differences were found also in the various plant spacing. In the highest density, we found the lowest \% yield loss. On the contrary in the lowest density, this parameter was the highest.

\section{CONCLUSIONS}

Five white cabbage cultivars were evaluated in 2001 and 2002 for the best combination of planting spacing for advancing growth and for obtaining highest marketable yield and head quality. It should be noted that the experiment was stressed by unfavourable growing conditions in the 2001. Very high temperatures in first year led to some reduction in yield potential and enlarge ratings of damage of thrips tabaci.

At the widest spacing treatment the marketable yield per head is highest. Therefore, we can conclude that plant at more space growth can use efficiently water, nutrients and solar radiation. On the other hand, higher plant spacing didn't significantly increase the marketable yield per hectare. These results are in correspondence with 
the findings of Semuli (2005) who mentioned that the greatest head weight resulting from increased spacing failed to compensate for the decreased number of heads that resulted from such spacing.

As expected, the effects of population spacing were primarily noted on yield and its characteristics but less on head quality.

Our experiment indicated that plant spacing can influence levels of herbivory. We have found that the damage ratings of thrips tabaci were generally higher in the sparse plots than in the dense plots. The mean damage rating of low spacing plots was 1.85 , while mean damage ratings in the high spacing plots was 1.42 .

\section{LITERATURE}

Agele, S.O., Iremiren, G.O., Ojeniyi, S.O. 1999. Effects of plant density and mulching on the performance of late-season tomato (Lycopersicon esculentum) in southern Nigeria. J. Agr. Sci. Cambridge, 133: 397-402.

Day, M.J. 1986. A comparison of yield and quality factors in two winter white cabbage cultivars at five population. J. Natl. Inst. Agric. Bot., 17, 2: 231-244.

Ghanti, P., Sounda, G., Jana, P.K., Som, M.G. 1982. Effect of levels of nitrogen, phosphorus and spacing on yield characters of cabbage. Veg. Sci., 9: 1-4.

Kahn, B.A., Edelson, J., Damicone, J.P. 2007. Cole crop production (Broccoli, Cabbage, and Cauliflower). Oklahoma Cooperative Extension Service, http://www.osuextra.com (02. Jan. 2007)

Kleiheinz, M. D., Wszelaki, A. 2003. Yield and relationships among heat traits in cabbage (Brassica oleracea, L. Capitata Group) as influenced by planting date and cultivar. I. Fresh market. HortScience, 38: 1349-1354.

Koutsos, T.V., Koutsika-Sotiriou, M. 2001. Effect of mass selection in nil-competition conditions on some traits of four cabbage populations. Plant Breed., 120: 93-95.

Kumar, M., Rawat, T.S. 2002. Effect of nitrogen and spacing on the quality and yield of cabbage (Brassica oleracea L. var. capitata). Agric. Sci. Digest, 22, 2: 90-92.

Lal, G. 1996. Effect of nitrogen and spacing on yield and quality of cabbage (Brassica oleracea L. var. capitata). Ann. Biol., 12, 2: 242-244.

Masaya, F., Kubota, C., Kozai, T., Sakami, K. 2004. Air temperature effect on leaf development in vegetative propagation of sweetpotato single node cutting under artificial lighting. Sci. Hort., 99: 249-256.

Parmar, H.C., Maliwal, G.L., Kaswala, R.R., Patel, M.L. 1999. Effect of irigation, nitrogen and spacing on yield of cabbage. Indian. J. Hort., 56, 3: 256-258.

Pearson, O.H. 1983. Methods of determining the solidity of cabbage heads. Hilgardia, 5: 383-393.

Radovich, T.J., Kleinhenz, M.D., Honeck, N.J. 2004. Important cabbage head traits and their relationship at five points development. J. Veg. Crop Prod., 10, 2: 19-32.

Raupp, J. 2000. Fertilization effects on products quality and examination of parameters and methods for quality assessment. (April, 2000), http://www.edis.ifas.ufl.edu (10. Jan. 2007). 
Semuli, K.L.H. 2005. Nitrogen requirements for cabbage (Brassica oleracea capitata) transplants and crop response to spacing and nitrogen top-dressing. M. Sc. Thesis, University of Pretoria, $57 \mathrm{p}$.

Siomos, A.S. 1999. Planting date and within-row plant spacing effects on pak choi yield and quality characteristics. J. Veg. Crop Prod., 4, 2: 65-73.

Stepanović, M.V., Bjelič, V.V., Dragičević, V.D. 2000. Effect of crop density on morphological characteristics and yield of cabbage. Acta Hort., 533: 205-207.

Statistical Office RS. 2005. Rapid Reports - provisional data. Ljubl., No. 311, Dec. 122005.

Stoffela, P.J., Bryan, H.H. 1988. Plant population influences growth and yield of bell pepper. J. Amer. Soc. Hort. Sci., 113: 835-839.

Stoffela, P.J., Fleming, M.F. 1990. Plant population influences yield variability of cabbage. J. Amer. Soc. Hort. Sci., 115, 5: 708-711.

Tamo, M., Baumgartner, J., Arodokoun, D. Y. 1993. The spatio-temporal distribution of Megalurothrips sjostedti (Trybom) (Thysanoptera, Thripidae) life stages on cowpea, and development of sampling plans. Mitt. Schweiz. Entomol. Ges., 66, 1-2: 15-34.

Tenday, M., Kuzyk, K. 2001. Effect of plant density on yielding of cabbage. Veg. Crops Res. Bull., 54, 2: 35-39.

Tiwari, K.N., Singh, P.K., Mal, P.K. 2003. Effect of drip irrigation on yield of cabbage (Brassica oleracea L. var. capitata) under mulch and non-mulch conditions. Agric. Water Manag., 58: 19-28.

Trdan, S., Milevoj, L., Žežlina, I., Raspudić, E., Anđus, L., Vidrih, M., Bergant, K., Valič, N., Žnidarčič, D. 2005. Feeding damage by onion thrips, Thrips tabaci Lindeman (Thysanoptera, Thripidae), on early white cabbage grown under insecticide-free conditions. Afr. Entomol., 13, 1: 85-95. 